\title{
Dampak Pembelajaran Daring pada Perkembangan Psikososial Anak Saat Pandemi COVID-19
}

\author{
Suyadi ${ }^{\square}$ \\ Pendidikan Islam Anak Usia Dini, Universitas Islam Negeri Sunan Kalijaga, Indonesia(1) \\ DOI: $\underline{10.31004 / o b s e s i . v 6 i 4.2349}$
}

\begin{abstract}
Abstrak
Selama masa pandemi COVID-19, pembelajaran online menjadi alternatif untuk penyelesaian masalah pendidikan di Indonesia. Keterbatasan pelaksanaan pembelajaran pembelajaran online di lembaga pendidikan anak usia dini mengakibatkan gangguan perkembangan pada anak. Penelitian ini bertujuan untuk mengetahui gangguan perkembangan apa saja pada anak usia dini selama pembelajaran online. Partisipan dalam penelitian ini adalah guru dan orang tua. Partisipan melibatkan 125 anak, 8 orang tua, dan 7 guru di 4 lembaga Pendidikan Anak Usia Dini di Yogyakarta. Metode penelitian yang digunakan adalah kualitatif dengan teknik deskriptif dan content analysis. Pengumpulan data primer dan sekunder dengan melakukan observasi lapangan dan wawancara. Display data penelitian dengan menggunakan program aplikasi ATLAS.ti. Hasil penelitian menemukan bahwa pembelajaran daring berpengaruh pada gangguan perkembangan psikososial yaitu terbatasnya interaksi anak dengan orang lain dan berkurangnya keterampilan anak berkomunikasi. Gangguan ini berimplikasi pada keterasingan anak dalam kehidupan sosialnya sehari-hari.
\end{abstract}

Keywords: covid-19; pembelajaran daring; perkembangan psikososial

\begin{abstract}
During the COVID-19 pandemic, online learning became an alternative to solving education problems in Indonesia. Limitations of the implementation of online learning in early childhood education institutions result in developmental disorders in children. This study aims to find out what developmental disorders in early childhood during online learning. Participants in the study were teachers and parents. Participants involved 125 children, 8 parents, and 7 teachers at 4 early childhood education institutions in Yogyakarta. The research method used is qualitative with descriptive techniques and content analysis. Primary and secondary data collection by conducting field observations and interviews. Display research data using the ATLAS.ti application program. The results of the study found that online learning has an effect on psychosocial developmental disorders, namely limited interaction of children with others and reduced children's skills.
\end{abstract}

Keywords: covid-19; online learning; psychosocial development

Copyright (c) 2022 Suyadi

$\triangle$ Corresponding author :

Email Address : suyadi@uin-suka.ac.id

Received 30 October 2021, Accepted 6 February 2022, Published 14 February 2022 


\section{PENDAHULUAN}

Pembelajaran online akibat pandemi COVID-19 telah mempengaruhi tingkat pencapaian perkembangan anak (Kristy L. Turner, Michael Hughes, 2020). Pencapaian perkembangan anak sangat ditentukan oleh stimulasi lingkungan. Minimnya stimulasi saat pembelajaran online telah mempengaruhi gangguan aspek-aspek perkembangan anak. Banyak guru mengalami kesulitan dalam pembuatan modul pembelajaran dan mengelola pembelajaran jarak jauh. Kesibukan orang tua karena bekerja mengakibatkan kurangnya pendampingan belajar dan bermain pada anak (Liu, 2020). Keterbatasan interaksi antara guru, orang tua, dan siswa (anak) memiliki andil besar terhadap tugas-tugas perkembangan anak yang tidak selesai (tercapai).

Studi tentang pembelajaran online akibat pandemi COVID-19 menunjukkan berbagai persoalan dalam kehidupan, khususnya bidang pendidikan anak usia dini yang menjadi salah satu sektor terdampak signifikan (Linhares, 2020). Hal ini akibat pemerintah Indonesia membuat kebijakan selama pandemic COVID-19 yang mewajibkan orang tua bekerja dari rumah (WFH) dan anak belajar dari rumah. Berdasarkan hasil riset terbukti kebijakan ini memberi trauma psikologis yang mengakibatkan meningkatnya stres pada orang tua dan terjadinya trauma pada anak (Suyadi \& Selvi, 2022). Seharusnya pembelajaran online menjadi alternatif sebagai pengganti pembelajaran langsung selama pandemi. Akan tetapi pembelajaran online tidak memberikan hasil yang cukup baik bagi anak terutama pendidikan anak usia dini di Indonesia.

Sistem pendidikan di Indonesia dalam menerapkan pembelajaran online pada pendidikan anak usia dini berdasarkan keputusan yang cepat. Hal ini tentu saja memberi kesan shock kepada orang tua. Mau tidak mau, orang tua dituntut menjadi guru bagi anak di rumah. Sesuai dengan hasil beberapa penelitian yang mengatakan, saat ini banyak orang tua tidak siap mendampingi anak belajar dengan sistem pembelajaran online ini (Lučić, 2020). Alasan paling signifikan adalah bentrokan antara pekerjaan dan mengajar anak. Kemudian kompetensi beberapa orang tua dalam mengajar anak belum seprofesional seorang guru. Sehingga orang tua kurang maksimal dalam memberikan bimbingan selama pembelajaran online kepada anak di masa pandemi COVID-19 ini.

Selain orang tua, guru juga memiliki kendala dalam melakukan pembelajaran online. Model pembelajaran interaksi langsung yang telah berlangsung lama menjadi salah satu faktor guru 'mati gaya' dalam menghadapi pembelajaran online yang minim interaksi dan sentuhan (Kim, 2020). Guru juga harus belajar kembali, menemukan ide-ide dan strategi dalam pembelajaran online sehingga materi pembelajaran tercapai pada anak meskipun dari jarak jauh. Sedangkan diketahui, bahwasannya bermain sambil belajar sebagai ciri khas pendidikan anak usia dini dalam menstimulasi perkembangan anak. Dengan demikian, ketidaksiapan orang tua mendampingi anak dan kesulitan guru mendesain dan mengelola pembelajaran daring sangat merugikan perkembangan anak.

Tulisan ini didasarkan pada argumen bahwa pandemi COVID-19 telah memberikan pengaruh langsung pada perkembangan anak selama mengikuti pembelajaran daring. Hasil penelelitian mengatakan bahwa sistem pembelajaran online selama pandemi menyebabkan keterbatasan interaksi anak dengan orang tua, anak dengan guru, maupun orang tua dengan guru (Zhao et al., 2020). Guru juga mengalami kesulitan komunikasi dan mendesain pembelajaran online karena ketidaktersediaan gadget memadai yang disediakan orang tua pada anak selama mereka ditinggal bekerja. Keterbatasan yang dipengaruhi oleh interaksi ini telah menjadi dasar bagi tercapainya perkembangan anak. Ketika orang tua kurang memberikan pendampingan saat anak bermain dan belajar, minimnya perangkat gadget yang disediakan untuk pembelajaran online, dan kesulitan guru dalam mendesain pembelajaran online maka anak akan mengalami kesulitan tumbuh kembang dengan baik (Bacher-Hicks et al., 2021). 
Tujuan penulisan ini adalah untuk melengkapi studi terdahulu tentang hubungan pembelajaran online selama pandemi COVID-19 dengan pencapaian perkembangan anak dengan cara menganalisis bagaimana pembelajaran online selama pandemi COVID-19 dapat menyebabkan gangguan perkembangan anak secara optimal. Sejalan dengan itu, tiga pertanyaan dijawab dalam penelitian ini: (a) bagaimana proses pembelajaran berlangsung yang dijalani anak, orang tua, dan guru di masa pandemi (proses belajar-mengajar, kesulitan yang dialami, cara mengatasi kesulitan); (b) bagaimana pembelajaran online menjadi faktor yang mempengaruhi aspek perkembangan anak; (c) bagaimana dampak pembelajaran online terhadap perkembangan anak. Ketiga pertanyaan tersebut memberi arah bagi pemahaman bahwa pandemi COVID-19 telah mendorong penguatan literasi digital, namun sekaligus memberi dampak gangguan perkembangan pada anak.

Kendala-kendala yang terjadi dalam pembelajaran online ini yang memberikan dampak pada anak usia dini. Dampak yang terjadi ialah gangguan dalam perkembangan psikososial anak usia dini. Pembelajaran online memberikan dampak gangguan perkembangan psikososial anak. Hal ini perlu menjadi perhatian bagi setiap orang tua bahwasannya anak masih membutuhkan bantuan orang tua selama pembelajaran online. Kesiapan mental orang tua dan pendampingan belajar anak dibutuhkan saat ini. Guru tidak bisa membawa pembelajaran langsung kepada anak. Sehingga orang tua merupakan harapan anak satu-satunya selama pembelajaran online.

Pendidikan Anak Usia Dini merupakan pendidikan yang paling fundamental karena perkembangan anak di masa selanjutnya akan sangat ditentukan oleh berbagai stimulasi bermakna yang diberikan sejak usia dini (Suyadi, 2019). Awal kehidupan anak merupakan masa yang paling tepat dalam memberikan dorongan atau upaya pengembangan agar anak dapat berkembang secara optimal. Penyelenggaraan layanan pendidikan anak usia dini secara profesional oleh negara maupun lembaga swasta akan memberi kontribusi positif terhadap tumbuh kembang anak.

Maka demikian, belajar untuk anak usia dini sangat penting sebagai bentuk stimulasi perkembangan anak yang optimal. Anak belajar berdasarkan dari pendidikan yang diberikan secara tepat (Suyadi \& Selvi, 2019). Perlu bagi orang tua untuk memantau perkembangan anak melalui belajar anak berdasarkan konsep belajar yang tepat dan menyesuaikan dengan kondisi pandemi COVID-19 saat ini. Implementasi belajar yang dilakukan anak adalah melalui pembelajaran online. Hal ini tentu saha akan merubah kebiazsaan anak dari bertatap muka langsung dengan orang lain, menjadi bertatap muka dibalik layar gadget. Kebiasaan baru ini perlu pendampingan orang tua dan guru secara maksimal. Karna anak masih perlu banyak belajar dan terus berkembang meskipun dengan keterbatasan interaksi.

Ternyata pembelajaran online selama pandemic COVID-19 yang seharusnya menjadi momentum pergeseran kebiasaan pembelajaran yang terkonsentrasi pada guru menjadi pembelajaran yang membebaskan, penggunaan teknologi yang pada dasarnya telah mendorong suatu cara "pembelajaran mandiri" yang melepaskan anak didik dari dominasi guru serta institusi pendidikan, semakin banyaknya waktu kebersamaan anak dan orang tua justru dalam kenyataannya telah menimbulkan berbagai gangguan perkembangan pada anak.

Pandemi COVID-19 telah menyebabkan penutupan sekolah di berbagai negara. Sekolah diminta memfasilitasi pembelajaran secara daring (UNICEF, 2020). Sejak sekolahsekolah ditutup pada awal Maret 2020, lebih dari 1,2 Milyar anak di dunia belajar di rumah. Pembelajaran tatap muka beralih menjadi pembelajaran online (Pangestu et al., 2021). Penguasaan keterampilan (literasi) digital menjadi faktor keberhasilan pola baru ini. Pembelajaran online telah mengubah cara pikir, sikap, dan perilaku (kebiasaan baru) masyarakat untuk terus melakukan aktifitas belajar-mengajar di tengah kondisi pandemi (Chamberlain, 2020).

Pembelajaran online memiliki dampak positif maupun negatif. Pergeseran secara tibatiba ini menyebabkan kesulitan bagi siswa, guru, dan orang tua (Li \& Lalani, 2020). Siswa yang mengikuti pembelajaran secara virtual (online) menunjukkan penurunan prestasi dalam 
kemampuan matematika, bahasa, seni, dan kinerja (Fitzpatrick et al., 2020). Banyak guru mengalami kesulitan dalam pembelajaran terkait penggunaan teknologi, desain kurikulum, dan keterampilan internet. Kesulitan bagi orang tua adalah minimnya infrastruktur perangkat daring serta minimnya waktu pendampingan belajar kepada anak (Li \& Lalani, 2020).

Pembelajaran online di masa pandemi COVID-19 telah menimbulkan persoalan kesulitan proses belajar-mengajar di masyarakat. Penutupan sekolah dan pemberlakuan pembelajaran online telah menyebabkan gangguan-gangguan perkembangan anak. Keharusan secara fisik menjaga jarak sebagai bagian protokol kesehatan melindungi masyarakat dari bahaya COVID-19 telah menciptakan persoalan baru dalam dunia pendidikan (Wasmuth, 2020). Pembelajaran secara tatap muka langsung beralih menjadi pembelajaran online jarak jauh. Keterbatasan akses internet, minimnya gadget yang dimiliki, penguasaan literasi digital, kurangnya interaksi dan pendampingan, serta tidak adanya inovasi pembelajaran menyebabkan pembelajaran online jarak jauh belum berjalan efektif memberikan dampak positif (Li \& Lalani, 2020). Berbagai persoalan tentang akses internet, gadget, literasi digital, interaksi, pendampingan, dan inovasi dalam pembelajaran online jarak jauh berpengaruh terhadap capaian pembelajaran.

Kemampuan mengakses internet, ketersediaan gadget, literasi digital, pendampingan orang tua, dan inovasi guru dalam pembelajaran telah mempengaruhi kualitas pembelajaran online jarak jauh yang berdampak pada perkembangan siswa (Dreifuss-Serrano, 2020). Pembelajaran online merupakan strategi pendidikan alternatif paling efektif di masa pandemi. Pembelajaran online mendapat beragam respon berupa keluhan dan kesulitan yang dialami oleh anak, orang tua, dan guru. Sehingga berdampak pada gangguan perkembangan pada anak (Khairi, 2018).

Gangguan perkembangan anak dapat dilihat dari tiga aspek yakni aspek perkembangan biologis, kognitif dan psikososial. Proses perkembangan biologis anak melibatkan perubahan fisik dalam tubuh individu. Aspek fisik berkaitan dengan pertumbuhan tubuh dan otak, kapasitas sensoris, keterampilan motor, dan kesehatan. Kemudian proses perkembangan kognitif pada anak melibatkan perubahan pemikiran dan intelegensi individu. Sedangkan aspek kognitif mempelajari atensi, memori, pemecahan masalah, proses berpikir, penalaran termasuk didalamnya penalaran moral, kreativitas, dan bahasa. Aspek psikososial meliputi perkembangan emosi, kepribadian, dan hubungan sosial (Talango, 2020). Dalam kajian ini akan mengangkat bagaimana gangguan perkembangan pada aspek psikosial anak usia dini dan kaitannya dengan pembelajaran online.

Tingkat capaian perkembangan siswa yang memiliki akses internet terbatas, kurangnya pendampingan belajar, dan minimnya literasi digital orang tua berbeda dengan siswa memiliki akses cukup, dan didampingi orang tua yang memiliki literasi digital yang memadai. Siswa dengan akses terbatas lebih mengalami kesulitas belajar dan interaksi dengan guru yang memanfaatkan media daring dalam proses belajar-mengajar. Sebaliknya, siswa dengan akses luas dan pendampingan memadai lebih mudah beradaptasi dengan model pembelajaran online jarak jauh yang diterapkan guru (Formosinho, 2021). Perbedaan akses dan pendampingan anak dalam pelaksanaan pembelajaran online jarak jauh berbanding lurus dengan tingkat ketercapaian perkembangannya.

\section{METODOLOGI}

Penelitian ini mengaitkan hubungan antara pembelajaran online jarak jauh dengan capaian perkembangan anak yang dijelaskan melalui metode penelitian kualitatif. Metode penelitian kualitatif digunakan untuk untuk mengungkapkan makna yang menginformasikan tindakan, memaknai, menginterpretasi, dan yang berkaitan dengan kehidupan sosial. Metode penelitian kualitatif yang bersandar pada data primer dan data sekunder. Data primer terdiri dari proses belajar-mengajar berlangsung, kesulitan-kesulitan belajar yang dihadapi siswa, ketersediaan media pembelajaran yang dipakai, tingkat partisipasi, dan solusi-solusi yang ditempuh atas setiap kesulitan. Data sekunder terdiri latar belakang orang tua siswa, 
kemampuan guru dalam mengelola pembelajaran online, dan hasil evaluasi capaian belajar siswa. Kedua data tersebut digunakan sebagai dasar analisis hubungan antara pembelajaran online jarak jauh dengan capaian perkembangan anak.

Penelitian ini melibatkan kelompok anak, kelompok orang tua dan guru di lembaga pendidikan anak usia dini dengan menggunakan teknik sampling. Sejumlah 15 partisipan yang diwawancarai yakni 7 orang guru dan 8 orang tua. Kemudian sejumlah 125 anak yang di observasi langsung saat pembelajaran online. Partisipan berasal dari 4 lembaga Pendidikan Anak Usia Dini seperti Taman Penitipan Anak (Daycare), Kelompok Bermain, Taman Kanakkanak dan Raudhatul Atfhal (RA) di Indonesia yang menerapkan sistem pembelajaran online saat pandemi COVID-19. Orang tua dalam mendampingi pembelajaran di rumah didentifikasi dengan berbagai karakteristik dan tipe kesulitannya masing-masing. Selanjutnya, guru juga dipetakan peran dan pengalamannya dalam proses belajar-mengajar selama pandemi. Guru pun mengalami berbagai akibat dari pemberlakuan pembelajaran online jarak jauh sebagaimana yang dialami oleh siswa dan orang tua. Ketiga kelompok partisipan diidentifikasi dari sumber lapangan untuk dikategorisasi pengalaman mereka dalam proses belajar-mengajar online selama pandemi.

Penelitian tentang "Hubungan antara pembelajaran online dengan gangguan perkembangan anak" berlangsung melalui tahapan pengumpulan data primer dan sekunder, observasi lapangan, wawancara orang tua dan guru. Pertama, Data primer dan sekunder dikumpulkan melalui dokumen yang dimiliki sekolah. Data tentang siswa biasanya selalu diperbaharui oleh sekolah minimal setiap satu semester sekali. Kedua, data yang bersumber pada lapangan dikumpulkan melalui observasi kepada siswa, orang tua, dan guru terkait proses pembelajaran online. Ketiga, Tulisan ini dilengkapi dengan data wawancara kepada orang tua dan guru. Baik siswa, orang tua, dan guru telah menerima akibat-akibat langsung dalam pemberlakuan pembelajaran online selama pandemi. Berbagai kategori data yang bersumber dari lapangan tersebut menjadi landasan bagi analisis hubungan antara pembelajaran online dengan capaian perkembangan anak. Karakteristik partisipan disajikan pada tabel 1 dan 2.

Tabel 1. Karakteristik Partisipan Anak Usia Dini

\begin{tabular}{ccccc}
\hline \multirow{2}{*}{ No } & \multirow{2}{*}{ Umur } & \multirow{2}{*}{ Kelas } & Laki-laki & Perempuan \\
\hline 1. & 4-6 Tahun & TK & 46 & 37 \\
2. & 3-4 Tahun & KB & 10 & 17 \\
3. & 0-3 Tahun & TPA & 10 & 5 \\
\hline \multirow{2}{*}{ Total } & & 66 & 59 \\
\hline
\end{tabular}

Tabel 2. Karakteristik Partisipan Orang tua dan Guru

\begin{tabular}{cccc}
\hline \multirow{2}{*}{ No } & \multirow{2}{*}{ Partisipan } & \multicolumn{2}{c}{ Gender } \\
& & Laki-laki & Perempuan \\
\hline 1. & Orang tua & 1 & 7 \\
2. & Guru TPA & 0 & 1 \\
& Guru KB & 0 & 1 \\
& Guru TK & 0 & 5 \\
\hline & Total & 1 & 14 \\
& & \multicolumn{2}{c}{15 partisipan } \\
\hline
\end{tabular}

Data dikumpulkan berdasarkan prosedur penelitian yang dilakukan yakni pengumpulan data, penyajian data, reduksi data dan verifikasi atau penarikan kesimpulan. Adapun bagan prosedur kajian penelitian ini sebagaimana disajikan pada gambar 1 . 


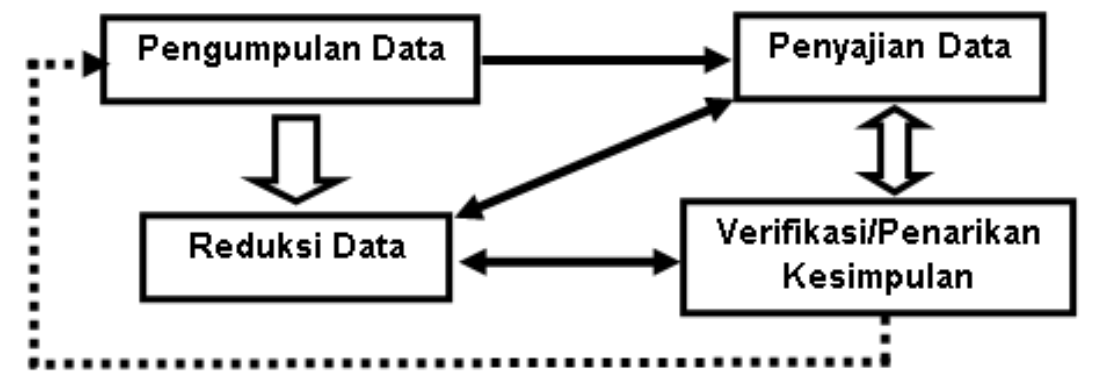

Gambar 1. Prosedur Penelitian

Sedangkan hasil data disesuaikan berdasarkan instrumen wawancara langsung kepada guru dan orang tua. Indikator instrumen meliputi bagaimana gambaran pembelajaran online selama pandemi, kendala yang diperoleh selama pandemi, dampak pembelajaran online terhadap perkembangan psikososial anak selama pandemi COVID-19. Kemudian, penelitian melakukan observasi langsung secara via online, dengan intrumen mengamati perilaku dan perkembangan anak sesuai dengan indikator perkembangan psikososial. Instrumen wawancara orang tua dan Guru disajikan pada tabel 3.

Tabel 3. Instrumen Wawancara Orang tua dan Guru

\begin{tabular}{|c|c|c|}
\hline No. & Aspek & Pertanyaan \\
\hline 1. & Pembelajaran online & $\begin{array}{l}\text { Bagaimana pendapat orang tua terhadap pembelajaran online? } \\
\text { Dalam satu minggu masuk berapa kali? } \\
\text { Metode pembelajaran online? }\end{array}$ \\
\hline 2. & $\begin{array}{l}\text { Kendala dalam } \\
\text { pembelajaran online }\end{array}$ & Kekurangan dan kelebihan dalam pembelajaran online? \\
\hline \multirow[t]{4}{*}{3.} & $\begin{array}{l}\text { Aspek perkembangan } \\
\text { psikososial }\end{array}$ & $\begin{array}{l}\text { Bagaimana pengembangan psikososial untuk anak dalam } \\
\text { pembelajaran online? }\end{array}$ \\
\hline & & $\begin{array}{l}\text { Bagaimana metode pembelajaran dalam mengembangkan } \\
\text { psikososial anak? }\end{array}$ \\
\hline & & $\begin{array}{l}\text { Bagaimana model pembelajaran dalam mengembangkan } \\
\text { perkembangan psikososial anak? }\end{array}$ \\
\hline & & Apa kendala psikosial anak selama pembelajaran online? \\
\hline
\end{tabular}

Proses analisis data berlangsung melalui tiga tahap analisis dan dua teknik analisis data. Tiga tahap analisis mencakup: (a) reduksi data sebagai proses penataan data dalam bentuk yang lebih sistematis, khususnya secara tematis; (b) display data sebagai usaha menghadirkan hasil penelitian dalam bentuk gambar dengan menggunakan program aplikasi ATLAS.ti; dan (c) verifikasi data sebagai suatu tahapan penyimpulan data, khususnya mengikuti tren dari data yang diperoleh. Data yang diproses melalui tiga tahap tersebut dianalisis melalui metode deskriptif dan content analysis. Deskripsi data sebagai dasar untuk proses interpretasi yang dilakukan secara kontekstual. Content analysis dilakukan mengikuti proses yang ditunjukkan oleh Spradley (2016). Tahapan analisis dan teknik analisis yang digunakan memungkinkan untuk merumuskan kesimpulan-kesimpulan atas hubungan antara pembelajaran online dengan capaian perkembangan anak di masa pandemi.

\section{HASIL DAN PEMBAHASAN}

Penelitian ini menghasilkan beberapa temuan yaitu mengenai gambaran pembelajaran online selama pandemi, kendala yang terjadi selama pembelajaran online, kemudian dampak dari pembelajaran online itu sendiri yang mempengaruhi perkembangan psikososial anak usia dini. Pembelajaran online selama pandemi COVID-19 di lembaga Pendidikan Anak Usia 
Dini sebagai alternatif untuk penyelesaian masalah pendidikan di Indonesia. Adapun gambaran tentang pembelajaran online selama pandemi hasil dari penelitian ini ditampilkan pada gambar 2.

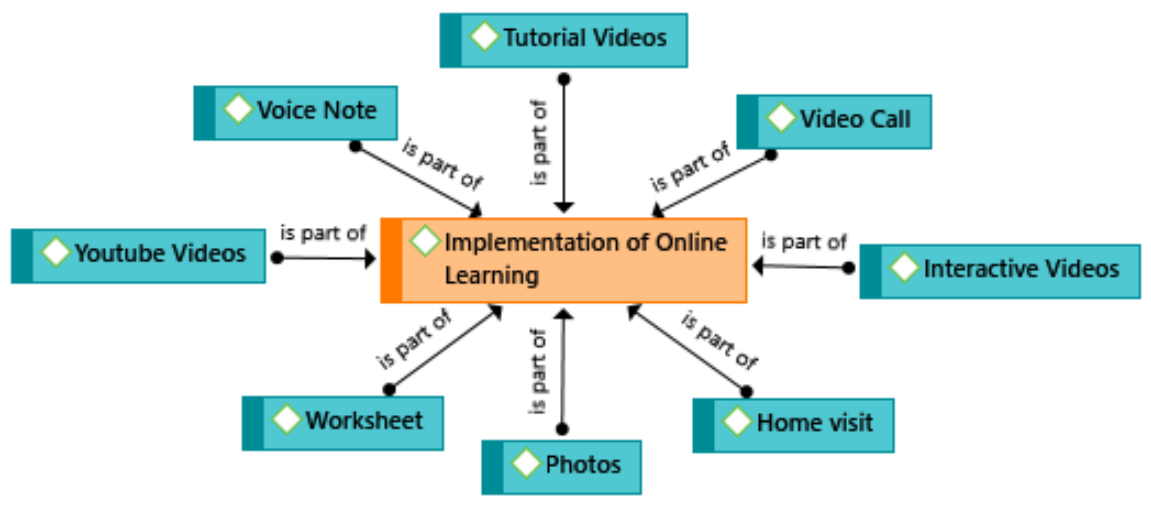

Gambar 2. By Atlas.ti: Implementation of Online Learning

Bagan pada gambar 2 merupakan penggambaran dari penerapan pembelajaran online yang terjadi dalam pendidikan anak usia dini di Indonesia. Penerapan pembelajaran online berupa video call dengan guru, pesan suara, menonton video youtube, worksheet yang diberikan kepada orang tua untuk kemudian dikerjakan anak di rumah, video tutorial, foto kegiatan yang dikirim melalui sosial media dan kunjungan guru ke rumah. Terkadang guru juga memantau anak dengan melakukan kunjungan ke rumah dalam sebulan sekali. Hal ini untuk memantau langsung perkembangan anak selama di rumah.

Orang tua dan anak menggunakan handphone untuk berkomunikasi dan berinteraksi dengan guru selama pembelajaran jarak jauh. Pelaksanaan pembelajaran online ini dilakukan dalam lima hari yakni hari senin hingga hari jumat. Hal ini disampaikan dalam kutipan wawancara dengan salah satu guru perempuan dari Taman Kanak-kanak, yakni sebagai berikut ini:

"Kami melakukan video call selama sepekan itu secara bersama-sama. Sesi pertama dengan tiga anak secara bersama-sama. Ada lagi sesi worksheet dan menonton youtube. Hari senin digunakan untuk video call bersama. Sedangkan selasa, rabu, dan kamis digunakan untuk video call secara mandiri. Saya sesuaikan kegiatan video call dengan kegiatan orang tua dan anak. Ada yang dilakukan sore hari, malam, dan pagi hari dengan target dalam satu pekan semua anak bisa video call bersama. (Wawancara guru perempuan dari TK, Kamis, 1 April 2021)."

Pembelajaran melalui video call untuk anak usia 3 sampai 6 tahun dilakukan menjadi dua sesi. Setiap sesi dibagi menjadi tujuh anak. Hal ini dilakukan karena melaksanakan pembelajaran online dan melakukan asesmen perkembangan dengan melibatkan semua anak secara bersamaan menjadi sulit dan tidak efektif. Selanjutnya orang tua membuat laporan harian perkembangan anak dan mengirimkan hasil tugas-tugas anak selama sepekan ke sekolah. Hal ini terlihat dari hasil observasi langsung melalui via daring menggunakan video conference yakni google meet bersama anak.

Gambar 3 menggambarkan tentang pembelajaran online selama pandemi yang dilakukan oleh anak-anak usia 3-6 tahun dari Taman Kanak-kanak dan Kelompok Bermain. Pembelajaran dilakukan menggunakan google meet. Anak-anak antusias mengikuti pembelajaran online meskipun tidak bisa secara langsung bertemu dengan gurunya. Selain video call melalui aplikasi google meet, whatsapp, dan zoom, pembelajaran online juga menggunakan media lain seperti voice note, worksheet, video tutorial, video interaktif, dan youtube. 


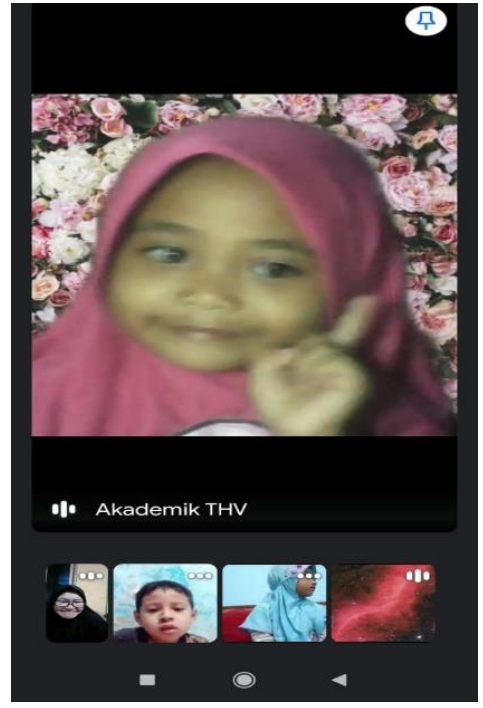

\section{Gambar 3. Learning by Google Meet}

Hal ini berbeda dengan anak yang berusia 2 tahun kebawah (Daycare), karena sangat sulit apabila menerapkan pembelajaran secara online. Sebagai gantinya guru melakukan kunjungan ke rumah siswa setiap dua kali dalam sebulan. Kegiatan ini difokuskan pada deteksi tumbuh kembang anak seperti kemampuan berjalannya, berat badannya, merangkak, kesehatan dan lainnya sebagimana yang disampaikan oleh salah satu guru Daycare yakni:

"Selama penutupan sekolah akibat pandemic, guru Daycare harus melakukan kunjungan ke rumah anak-anak. Hal ini dilakukan agar kami mengetahui sekaligus mencatat bagaimana perkembangan dan pertumbuhan anak selama di rumah. Kegiatan mengunjungi anak ke rumahnya kami lakukan setiap dua bulan sekali. (Wawancara guru perempuan dari Daycare, 31 Maret 2021)."

Selain kunjungan, dilakukan juga pemberian tugas kepada orang tua agar tetap menstimulasi anak dari rumah. Selanjutnya orang tua memberikan laporan harian yang ditugaskan oleh guru. Misalnya, penugasan anak untuk memasukkan bola-bola ke dalam keranjang. Selanjutnya orang tua akan mengambil foto dan video untuk dikirimkan ke guru pada hari itu juga. Ketika guru tidak bisa melakukan home visit, maka guru akan melakukan video call kepada orang tua untuk memantau perkembangan anak. Kegiatan seperti ini terus menerus dilakukan selama masa pandemi. Hal ini tentu saja tidak selamanya berjalan sesuai harapan. Kendala utama yang terjadi adalah hampir semua orang tua sibuk bekerja.

\section{Kendala Pembelajaran online}

Untuk membawa suasana belajar sekolah ke rumah, guru juga memberikan tugas worksheet sebagai pekerjaan rumah anak. Terkadang pembelajaran juga dilakukan dengan menonton video tutorial, video interaktif, dan youtube. Meskipun pembelajaran online sebagai alternatif selama pandemi COVID-19, akan tetapi hasil temuan memperoleh terdapat beberapa kendala selama pembelajaran online berlangsung. Hal ini tentu saja akan mempengaruhi perkembangan anak. Adapun beberapa kendala yang terjadi selama pembelajaran online saat pandemi yakni yakni digambarkan pada gambar 4 .

Berdasarkan display gambar 4, diketahui bahwasannya terdapat beberapa kendala yang terjadi selama pembelajaran online yaitu sebagai berikut: 1) kebijakan lockdown yang berubah-ubah (tidak konsisten), 2) orang tua yang sibuk, 3) sinyal yang buruk, 4) keterbatasan kemampuan orang tua dalam mengajar, 5) tugas yang dikerjakan tidak sesuai dengan instruksi guru, 6) anak banyak mengerjakan tugas saat malam hari ketika orang tua pulang kerja, 7) komunikasi anak dengan orang lain berkurang, 8) kebanyakan tugas anak dikerjakan dan diselesaikan oleh orang tua, 9) anak sering telat mengumpulkan tugas, 10) orang tua 
merasa terbebani dengan tugas mengajar, 11) anak malas-malasan, 12) anak mudah mengantuk.

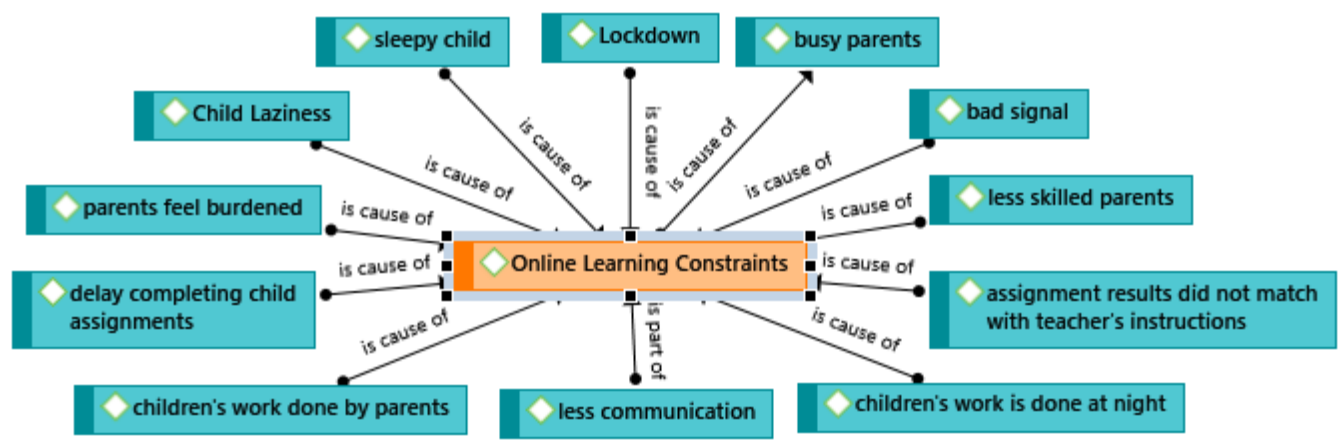

\section{Gambar 4. By Atlas.ti: Online Learning Constraints}

Kendala saat pembelajaran online yaitu adalah sinyal yang buruk, pengiriman tugas anak yang sering ditunda-tunda oleh orang tua, kebijakan lockdown yang berubah-ubah, kesibukan orang tua, kemalasan anak, orang tua yang merasa terbebani dengan tugas anak, hasil tugas yang tidak dikerjakan sesuai petunjuk guru, tugas-tugas anak dikerjakan saat malam hari, tugas anak dikerjakan oleh orang tua, anak yang telah mengantuk karena diminta belajar malam hari, keterampilan orang tua yang kurang, serta komunikasi orang tua dan anak yang kurang.

Pembelajaran online tentu saja membutuhkan media dan akses yang bagus dan baik agar pelaksanaan kegiatan belajar berjalan seperti yang diharapkan. Akan tetapi tidak selamanya pembelajaran itu berjalan baik. Seperti halnya terdapat kendala sinyal yang buruk. Hal ini membuat pembelajaran terganggu dan membuat anak semakin tidak fokus. Kemudian selama pandemi, kebijakan pemerintah yang sering berubah-ubah karena sebaran virus corona yang semakin meningkat. Sehingga anak dan orang tua menjadi bingung, terkadang anak harus berangkat ke sekolah, terkadang sekolah diliburkan, kemudian sekolah dibuka kembali.

Kendala yang terjadi ini juga memberi dampak negatif pada anak. Anak dituntut juga untuk mengumpulkan tugas melalui gawai. Sehingga dampak lainnya anak kecanduan menggunakan gawai dan banyak menghabiskan waktu menonton youtube. Hal ini dilihat dari hasil wawancara dengan beberapa narasumber orang tua yang mengatakan bahwa pembelajaran melalui youtube membuat anak kecanduan untuk terus menonton dan tidak membuka link youtube sebagaimana tugas dari sekolah.

"Susahnya itu di gadget, anak tidak mau melepaskan handphone yang digunakan. Alternatif lain saya berikan kaca mata anti radiasi untuk mengurangi dampak penggunaan handphone terlalu lama. Kalau bermain handphone saya berikan kaca mata anti radiasi, akan tetapi bila sudah waktunya makan dan beribadah, saya ambil terlebih dahulu handphone tersebut, setelah istirahat baru saya berikan kembali. (Wawancara Orang tua Kelompok Bermain, Kamis, 1 April 2021)"

Berdasarkan laporan guru kendala lain yang dihadapi adalah orang tua sering terlambat mengirimkan laporan perkembangan anak selama rumah. Anak juga sering tidak menyelesaikan tugas-tugas yang diberikan. Temuan lainnya menunjukkan bahwa orang tua terlalu sibuk bekerja sehingga kurang bisa mendampingi belajar dan memantau perkembangan anak. Hasil wawancara guru perempuan dari Taman Kanak-kanak Rabu, 31 Maret 2021, mengatakan bahwa "Waktu belajarnya ada saat malam hari karena orang tua pulang bekerja sudah sore atau malam hari." Selain itu mereka juga tidak bisa mengirim laporan perkembangan dan tugas anak karena pembelajaran online baru bisa dilakukan pada malam hari antara pukul 06.30-08.00 pm. 
Pembelajaran saat malam hari juga memiliki beberapa kendala, yakni beberapa anak sudah mulai mengantuk atau lelah bermain, beberapa orang tua tidak paham dengan petunjuk penyelesaian tugas ke anak, tugas anak dikerjakan oleh orang tua, orang tua kurang terampil dalam merangsang anak agar mau mengerjakan tugas, bahkan beberapa orang tua merasakan bahwa pembelajaran online ini merupakan suatu beban bagi orang tua. Seperti halnya hasil wawancara guru perempuan dari Taman Kanak-kanak pada hari Rabu tanggal 31 Maret 2021, yang mengatakan bahwa "Pembelajaran online seharusnya membuat komunikasi yang baik antara anak dan orang tua jadi lebih intens, akan tetapi ada beberapa orang tua yang mengeluh dan menganggap itu sebuah beban orang tua." Pembelajaran online harusnya menjadi sebuah alasan untuk meningkatkan semangat belajar anak di rumah dan kehangatan keluarga namun dalam prakteknya justeru merugikan aspek-aspek perkembangan anak.

\section{Dampak Pembelajaran online Terhadap Perkembangan Psikososial Anak}

Hasil temuan penelitian menemukan bahwasannya terjadi gangguan dalam aspek perkembangan psikososial anak selama pembelajaran jarak jauh. Gangguan perkembangan aspek psikososial meliputi perkembangan emosi, kepribadian, dan hubungan sosial. Beberapa kasus yang ditemukan pada anak adalah sikap anak yang lebih agresif dari pada biasanya, mudah ambekan dan marah-marah, kurang disiplin, kurang bersosialisasi, sikap malas, pemalu, lebih independen dan suka sendiri, sering menangis, dan mogok belajar. Adapun gambaran mengenai dampak pembelajaran online terhadap perkembangan psikososial anak sebagaimana disajikan pada gambar 5 .

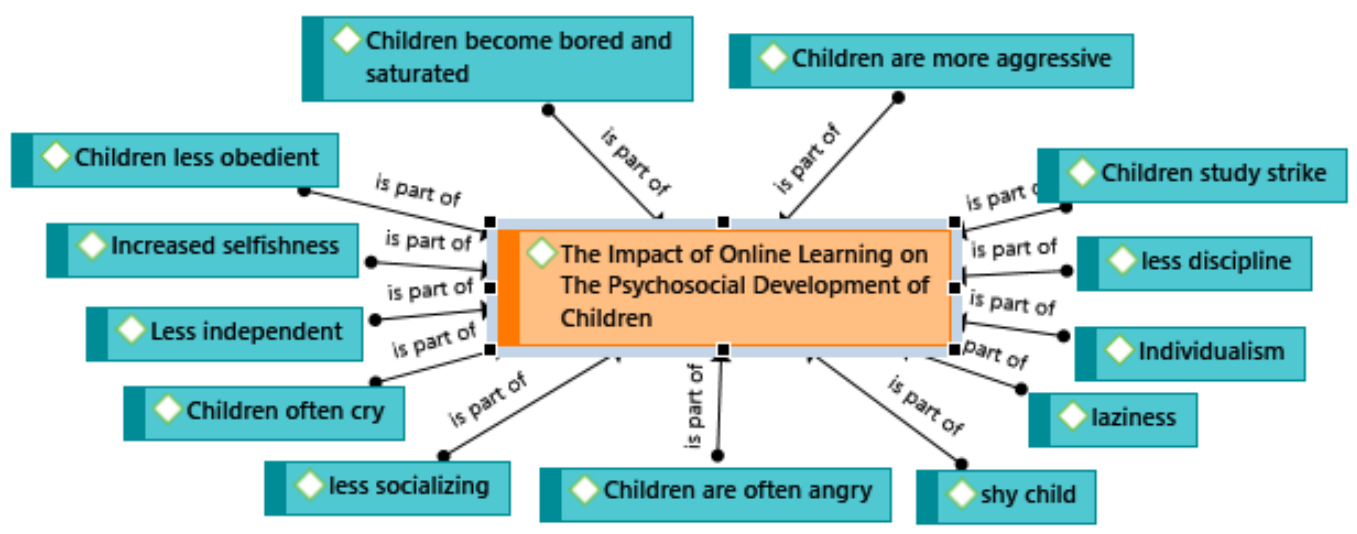

\section{Gambar 5. By Atlas.ti: The Impact of Online Learning on The Psychosocial Development of Children}

Berdasarkan display gambar 5, dampak yang terjadi pada perkembangan psikosial anak terbagi menjadi sebagai berikut: 1) anak mudah bosan dan jenuh dalam belajar, 2) anak lebih agresif, 3) anak kurang patuh dalam mengikuti instruksi, 4) anak cenderung individual, 5) anak lebih sering menangis, 6) anak kurang dalam bersosialisaasi, 7) anak cepat marah, 8) anak malas dalam mengerjakan tugas, 9) anak kurang disiplin, 10) anak sering mogok belajar.

Kendala-kendala yang terjadi selama pembelajaran jauh mengakibatkan banyak anak mengalami perubahan emosi, kepribadian dan menurun kemampuan bersosialisasi. Hal ini disampaikan langsung oleh guru dan orang tua yang mengatakan bahwa perkembangan psikososial anak mengalami perubahan selama pembelajaran jarak jauh. Seperti halnya hasil wawancara dengan orang tua salah satu murid dari Taman Kanak-kanak (Kamis, 13 April 2021):

"Kalau di rumah anak menjadi lebih tertutup. Saat di rumah, anak kalau bermain sama teman tidak menyenangkan seperti di sekolah. Anak saya itu mudah berbaur sama orang lain. Tapi kalau di rumah, anak saya tidak mau bersosialisasi dan tidak suka saat temannya mengajak bermain. Saat temannya datang ke rumah, anak saya tidak betah bahkan meminta temannya 
untuk pulang saja. Anak saya memberikan alasan bahwa anak saya ingin tidur. Saat temannya sudah pulang, ternyata anak saya bermain handphone. Intinya anak saya tidak suka saat temannya datang ke rumah"

Selama pembelajaran online anak sulit bersosialisasi. Dimana anak lebih sering dan nyaman menggunakan handphone sebagai teman bermain. Sehingga ketika ada teman yang berkunjung ke rumah, anak lebih suka main sendirian. Hal ini tentu saja harus menjadi perhatian lebih bagi orang tua karena menurunnya perkembangan sosial anak terhadap lingkungan di sekitarnya. Selain sosial anak yang mulai mengalami penurunan, anak mulai bersikap individualis. Hasil wawancara orang tua dari Taman Kanak-kanak yang menyatakan sebagai berikut: "Kalau pagi, anak saya tidak pernah keluar rumah. Anak saya keluar rumah sebentar, tidak lama kemudian pulang kembali. Anak saya sulit bermain dengan temannya. Dia juga tidak pernah ketemu orang banyak." Sikap anak yang sedemikian rupa ini membawa anak kian menjadi sosok orang yang lebih pemalu, pendiam, pemalas, dan egois. Hal ini ditemukanya sebagian anak selama pembelajaran jarak jauh, memiliki karakter egois. Anak tidak suka berbagi mainannya dengan temannya, tidak mau mengakui kesalahan, dan tidak mau mengalah.

Pembelajaran online memberikan dampak tidak terlalu baik untuk perkembangan anak. Anak mengalami beberapa ketidakcapaian perkembangan selama pelaksanaan pembelajaran online jarak jauh. Hasil temuan mendapatkan bahwa anak mengalami ketidakcapaian perkembangan dalam aspek psikososial. Hal ini berdasarkan hasil temuan lapangan yang melibatkan beberapa guru dan orang tua anak dari lima lembaga sekolah di Indonesia. Keadaan ini membuat anak mengalami perubahan yang cukup signifikan. Anak seharusnya mencapai perkembangan yang optimal di usia saat ini. Maka dari itu pembelajaran online dirasa kurang efektif untuk perkembangan anak.

Selaras dengan hasil penelitian yang mengatakan bahwa pembelajaran online tidak efektif untuk diterapkan pada anak usia dini karena jaringan internet yang kurang stabil, anak tidak fokus saat memperhatikan guru hanya di layar aplikasi, anak tidak terlalu tertarik pada pembelajaran secara online karena anak membutuhkan perhatian langsung saat proses pembelajaran, sementara pada saat pembelajaran online, guru tidak dapat memberikan perhatian secara langsung kepada anak (Satriana et al., 2021).

Pembelajaran online memberikan dampak pada aspek perkembangan psikososial. Hasil temuan penelitian menemukan bahwasannya terjadi gangguan dalam aspek perkembangan psikososial anak selama pembelajaran online. Gangguan perkembangan aspek psikososial meliputi perkembangan emosi, kepribadian, dan hubungan sosial. Beberapa kasus yang ditemukan pada anak adalah sikap anak yang lebih agresif dari pada biasanya, mudah ambekan dan marah-marah, kurang disiplin, kurang bersosialisasi, sikap malas, pemalu, lebih independen dan suka sendiri, sering menangis, dan mogok belajar.

Pembelajaran daring sangat berdampak perilaku sosial emosional anak usia dini. Pembelajaran daring berdampak pada perilaku sosial emosional anak sebagai berikut anak kurang bersikap kooperatif karena anak jarang bermain bersama, kurangnya sikap toleransi kurangnya bersosialisasi dengan teman terbatasi adanya belajar dirumah, emosi anak yang terkadang merasa bosan dan sedih, anak merasa rindu teman dan guru serta anak juga tercatat mengalami kekerasan verbal karena proses belajar yang lazim. Hasil penelitian ini dapat dijadikan referensi untuk mengevaluasi pelaksanaan pembelajaran daring atau belajar dari rumah, mengingat pembelajaran daring akan terus berlanjut (Kusuma \& Sutapa, 2020).

Kasus selanjutnya ditemukan bahwa anak mengalami gangguan kesehatan mental yakni kecanduan terhadap gawai dan perubahan mood yang tidak terarah. Hal ini dilihat dari anak-anak yang tidak mau dilepas dari gawai. Kegiatan yang anak lakukan seperti bermain game online, menonton video youtube dan aktivitas hp lainnya. Kebiasaan anak menggunakan hp memberi pengaruh pada perasaan anak yang sering berubah-ubah. Seperti misalnya anak lebih sering merajuk dan ambekan. Orang tua merasakan anak lebih agresif dan sulit diatur selama pembelajaran jarak jauh. Hal ini terjadi selama pembelajaran online 
anak selalu diam di rumah, main handphone, tidak banyak aktifitas, terutama selalu ditinggalkan oleh orang tua yang masih bekerja di luar rumah.

Pencapaian perkembangan anak harus sejalan dengan pola pendidikan yang dilakukan selama pandemi COVID-19. Anak harus dibiasakan dan beradaptasi dengan kondisi pembelajaran online. Saat ini seharusnya anak usia dini dapat berkembang sesuai dengan tingkat pencapaian perkembangan yang optimal. Hasil penelitian ini mengungkapkan bahwa untuk pembelajaran online memiliki banyak kendala-kendala yang dapat menyebabkan ketidaktercapaian perkembangan anak. Ketidaktercapaian pada aspek perkembangan psikososial. Hasil temuan ini bertujuan menjadi acuan orang tua sebagai tambahan wawasan dan bentuk antisipasi agar tidak terjadi lagi ketidakcapaian perkembangan anak di masa pandemi.

\section{SIMPULAN}

Hasil penelitian memberikan wawasan pada orang tua bahwa telah terdapat penurunan kualitas perkembangan yang terjadi selama pembelajaran online. Gangguan perkembangan anak berupa menurunnya perkembangan psikososial anak. Adapun beberapa faktor yang mempengaruhi adalah kesibukan orang tua, susah sinyal, pembelajaran dilakukan malam hari, anak yang malas-malasan, mengantuk dan jenuh, kurangnya kemampuan mengajar orang tua ke anak, kurangnya komunikasi guru dan orang tua, tekanan dari orang tua, serta pengerjaan tugas yang tidak sesuai instruksi guru. Sehingga penelitian ini memberikan implikasi sebagai bentuk pencegahan gangguan perkembangan terhadap anak. Hal ini agar orang tua siap menjadi guru yang terbaik untuk perkembangan anak secara optimal di rumah.

\section{UCAPAN TERIMA KASIH}

Terimakasih saya ucapkan sebesar-besarnya kepada UIN Sunan Kalijaga untuk bantuan dan dukungan atas penelitian ini.

\section{DAFTAR PUSTAKA}

Bacher-Hicks, A., Goodman, J., \& Mulhern, C. (2021). Inequality in household adaptation to schooling shocks: Covid-induced online learning engagement in real time. Journal of Public Economics. https:// doi.org/10.1016/j.jpubeco.2020.104345

Chamberlain, L. (2020). Literacy in Lockdown: Learning and Teaching During COVID-19 School Closures. Reading Teacher, 74(3), 243-253. https:// doi.org/10.1002/trtr.1961

Dreifuss-Serrano, C. (2020). Early childhood online education in the COVID-19 context. Behavioral Patterns for User Interface Design. In Proceedings of 2020 IEEE Learning With MOOCS, LWMOOCS 2020 (pp. 90-95). https:// doi.org/10.1109/LWMOOCS50143.2020.9234385

Fitzpatrick, B., Berends, M., Ferrare, J. J., \& Waddington, R. J. (2020). Virtual charter schools and online learning during COVID-19.

Formosinho, J. (2021). From schoolification of children to schoolification of parents?educational policies in COVID times. European Early Childhood Education Research Journal, 29(1), 141-152. https:// doi.org/10.1080/1350293X.2021.1872677

Khairi, H. (2018). Karakteristik Perkembangan Anak Usia Dini dari 0-6 Tahun. Jurnal Warna, 2(2).

Kim, A. W. (2020). Evaluating the mental health impacts of the COVID-19 Pandemic: Perceived risk of COVID-19 infection and childhood trauma predict adult depressive symptoms in Urban South Africa. Psychological Medicine. https://doi.org/10.1017/S0033291720003414

Kristy L. Turner, Michael Hughes, and K. P. (2020). Learning Loss, a Potential Challenge for Transition to Undergraduate Study Following COVID19 School Disruption. American 
Chemical Society and Division of Chemical Education, J. Chem. E. https://doi.org/10.1021/acs.jchemed.0c00705

Kusuma, W. S., \& Sutapa, P. (2020). Dampak Pembelajaran Daring terhadap Perilaku Sosial Emosional Anak. Jurnal Obsesi: Jurnal Pendidikan Anak Usia Dini, 5(2). https://doi.org/10.31004/obsesi.v5i2.940

Li, C., \& Lalani, F. (2020). The COVID-19 pandemic has changed education forever. This is how.

Linhares, M. B. M. (2020). Reflections based on psychology about the effectof COVID-19 pandemic on child development. Estudos de Psicologia (Campinas), 37, 1-13. https:// doi.org/10.1590/1982-0275202037e200089

Liu, C. H. (2020). Psychosocial Stress Contagion in Children and Families During the COVID19 Pandemic. In Clinical Pediatrics (Vol. 59, Issue 9, pp. 853-855). https:// doi.org/10.1177/0009922820927044

Lučić, L. (2020). Effects of COVID-19 related restrictive measures on parents of children with developmental difficulties. Journal of Children's Services. https:// doi.org/10.1108/JCS-07-2020-0041

Pangestu, D. P., Na'imah, N., Rachmy Diana, R., Putro, K. Z., \& Saraswati, D. A. (2021). Implementation of Healthy Living Behavior of Early Childhood during the Covid-19 Pandemic. JOYCED: Journal of Early Childhood Education, 1(2), 62-73. https://doi.org/10.14421/joyced.2021.12-02

Satriana, M., Buhari, M. R., Makmun, M., Maghfirah, F., Haryani, W., Wahyuningsih, T., Wardana, H., Sagita, A. D. N., Oktamarina, L., \& Bakar, A. A. (2021). Persepsi Guru PAUD terhadap Pembelajaran Online: Fenomena Masa Pandemi Covid-19. Jurnal Obsesi : Jurnal Pendidikan Anak Usia Dini, 6(1), 362-373. https://doi.org/10.31004/obsesi.v6i1.1353

Spradley, J. P. (2016). Participant Observation. Waveland Press.

Suyadi, \& Selvi, I. D. (2022). Online learning and child abuse: the COVID-19 pandemic impact on work and school from home in Indonesia. Heliyon, 8(1), e08790. https:// doi.org/10.1016/j.heliyon.2022.e08790

Suyadi, S., \& Selvi, I. D. (2019). Implementasi Mainan Susun Balok Seimbang Berbasis Kearifan Lokal Yogyakarta untuk Anak Usia Dini. Jurnal Obsesi : Jurnal Pendidikan Anak Usia Dini, 4(1). https:// doi.org/10.31004/obsesi.v4i1.345

Suyadi. (2019). Services to children with developmental delays in early childhood education. International Journal of Scientific and Technology Research, 8(10), 2080-2084.

Talango, S. R. (2020). Konsep Perkembangan Anak Usia Dini. Early Childhood Islamic Education Journal, 1(1). https:// doi.org/10.54045/ecie.v1i1.35

UNICEF. (2020). Covid-19 and Children in Indonesia. https://www.unicef.org/indonesia/id/laporan/covid-19-dan-anak-anak-diindonesia

Wasmuth, H. (2020). Early childhood education and care in a post-pandemic world: The possibility of reimaging the child as an other. Knowledge Cultures, 8(2), 87-95. https://doi.org/10.22381/KC82202012

Zhao, Y., Guo, Y., Xiao, Y., Zhu, R., Sun, W., Huang, W., Liang, D., Tang, L., Zhang, F., Zhu, D., \& Wu, J. L. (2020). The effects of online homeschooling on children, parents, and teachers of grades 1-9 during the COVID-19 pandemic. Medical Science Monitor, 26, 110. https://doi.org/10.12659/MSM.925591 